\title{
Székelymagyar nemzeti- és kulturálisidentitás-stratégiák a trianoni határokon túl (Székely-Hungarian National and Cultural Identity Strategies beyond the Trianon Borders)
}

\section{Erzsébet Dani}

\begin{abstract}
In twenty-first century Europe the issue of majority/minority conflicts, national identity, and different forms of intercultural communication have become more and more foregrounded. Hungarian identity is a complex problematic in itself because Hungary suffered a serious historical trauma as a result of the 1921 Trianon treaties, in which Székely-Hungarians present an interesting case. This ethnic group had always had an identity of its own in Transylvania. However, the post-Trianon situation differs in that while formerly the Székelys defined themselves and claimed self-determination within (Hungarian) culture, they now found themselves in a multicultural world, in which no permissive multiculturality was allowed in the sense we conceive multiculturalism today. They were trapped in an antagonistic intercultural situation, where the borders were redrawn around them so that without leaving their homeland they nevertheless became beyond-the-borders citizens, which has led them to the need to apply various identitymanagement strategies. Post-Trianon Székely literature documents this very struggle of intercultural communication and identity-management strategies. Paradoxically, Transylvanian literature owes its existence as an autonomous entity to Trianon. It is by examining literary texts by Áron Tamási, Rózsa Ignácz, and György Bözödi that I am going to set up a typology of identity-management as reflected in the literature under discussion, a typology which this literature would not yield through traditional critical methods, and one which could be helpful in dealing not only with Székely literature in particular, but with contemporary European intercultural communicative crises in general.
\end{abstract}

Keywords: National and Cultural Identity, Cultural Memory, Identity-Management Strategies, Trianon, Székely-Hungarian Literature

Biography: Erzsébet Dani is Assistant Professor at the University of Debrecen, Hungary, where she teaches courses in the fields of library and information science, culture, and literature. She graduated from Eszterházy Károly College (Eger, 2000_LIS), and from Eötvös Lóránd University (Budapest, 2002 — postgraduate degree in management, library science), and was awarded her Ph.D. by the Eötvös Loránd University Doctoral Program for Literature and Cultural Studies in 2008. Her general research interest are: intercultural communication; Hungarian national and cultural identity as reflected in Hungarian literature; and education, culture, and information sources in the European Union. She has published a wide range of articles and two monographs.

(cc) BY

ULLS D-Serle
New articles in this journal are licensed under a Creative Commons Attribution 4.0 International License.

This journal is published by the University Library System of the University of Pittsburgh as part of its D-Scribe Digital Publishing Program and is cosponsored by the University of Pittsburgh Press 
Dani, Erzsébet. "Székelymagyar nemzeti- és kulturálisidentitás-stratégiák a trianoni határokon túl (SzékelyHungarian National and Cultural Identity Strategies beyond the Trianon Borders)." Hungarian Cultural Studies. eJournal of the American Hungarian Educators Association, Volume 9 (2016): http://ahea.pitt.edu DOI:

\section{Történelmi háttér (dióhéjban)}

A Kárpát-medencei magyarság egyik legnagyobb történelmi traumája az 1920. június 4én született trianoni békeszerződés, melynek értelmében a Magyar Királyság elvesztette területének és nemzeti vagyonának kétharmadát, és több mint három millió magyar maradt az országhatárokon kívül (Romsics 2012: 9). Az elszakított területek közül Romániához került Erdély, vele Kelet-Magyarország jelentős területei és több mint két millió magyar lélek (az 1910es népszámlálás szerint). Az újonnan formálódott román államban a nemzetiségi kérdés megkerülhetetlen volt, hiszen a nemzetiségiek aránya az össznépességnek több mint egyharmadát képezte. Jogaik biztosítása azonban állandóan problémákba ütközött, mert Románia egyértelmüen román belügyként óhajtotta kezelni a kisebbségi kérdést. Az Erdélyre vonatkozó nemzetiségi adatokat a románok a következőképpen határozták meg. A 4854397 lakosú területen mintegy 1664986 magyar (a tényleges 2012090 helyett. Ez a szám úgy állt elő az 1910-es népszámlálásból, hogy a székelyeket külön népcsoportnak vették, és a zsidók számát a magyarságból vonták le), 295133 német (a tényleges 322383 helyett), és 2519215 román (a tényleges 2346478 helyett-a rutének és a szerbek kivételével az összes görög katolikust és görögkeletit, valamint görög vallású cigányt románnak minősítették). A békekonferencián a memorandumhoz csatolt kimutatás az 1910-es népszámlálási adatokat követte, a nemzetiségi adatok megfelelő “helyesbítésével.”A további, ekkor már román népszámlálások $(1919,1920$, 1923, 1927, 1930) nemzetiségi adatai a magyar lakosság egyre csökkenő tendenciáját mutatják. Ez a jelenség, a statisztikai manipulációkon kívül, a kivándorlásnak is köszönhető, hiszen magyarok százezrei hagyták el Romániát, és repatriáltak Magyarországra (Bodonyi 2002: 105 106). A nyíltan ugyan nem vállalt, mégis erőteljes román asszimilációs törekvések eszköze volt az 1923. március 28 -án elfogadott alaptörvény ${ }^{1}$ is, melyben a kisebbségek sorsa megpecsételődött. Az Alkotmány egyértelmüen fogalmaz: “A román királyság egységes és osztatlan nemzeti állam” (Nagy 1944: 223). Porhintő módon, az alaptörvény mindenki számára toleránsan biztosítja a gondolat-, a vélemény- és a sajtószabadságot. Az 5. szakaszban azonban egyértelmüen felsejlik az erőszakos asszimiláció logikája: a "románok faji, nyelvi és vallási különbségre való tekintet nélkül élvezik a lelkiismereti szabadságot, a tanszabadságot, a gyülekezési szabadságot, az egyesülési szabadságot, továbbá különbözö, a törvények által megállapított összes szabadságokat és jogokat" (Balogh 2001: 85).

Témám tekintetében különösen fontos részletek ezek, hiszen a többségi állam törvénykezése jogi keretekbe foglalja: a kisebbség megfosztatik önazonosságától. Mert hiszen a logika csak látszólag zavaros (mit értsünk azon, például, hogy “nyelvi különbségre való tekintet nélkül," amikor a román, románul beszél; hol a nyelvi különbség?), valójában nagyon is világos: a "faji, nyelvi és vallási különbség” igenis létezik, de egyetlen feltétellel megtürt az erőszakos asszimilációs térben: ha románná válik. Mint látni fogjuk, nem kevés, húsba-vérbeegzisztenciába vágó interkommunikációs és identitáskálvária következik ebből azok számára, akik kisebbségi sorsát ennek a logikának a malmai kezdték örölni Trianon után.

\footnotetext{
${ }^{1}$ Megjegyzendő, hogy az 1923-as román alkotmány nem a tételes alkotmányjogi szabályok szerint jött létre. A nemzetgyülés túlnyomórészt liberális törvényhozói az elégedetlenséget nyíltan megfogalmazó ellenzéki pártok ellenében alkották meg. A Magyar Párt nem lehetett partner az előkészítő tárgyalásokon.
} 
Dani, Erzsébet. "Székelymagyar nemzeti- és kulturálisidentitás-stratégiák a trianoni határokon túl (SzékelyHungarian National and Cultural Identity Strategies beyond the Trianon Borders)." Hungarian Cultural Studies. eJournal of the American Hungarian Educators Association, Volume 9 (2016): http://ahea.pitt.edu DOI:

\section{A székelység és Székelyföld (dióhéjban)}

Székelyföld mint közigazgatási egység a tizenharmadik század elején jött létre (Rugonfalvi 2009: 144) és ilyen formában létezett az 1876-os megyerendezésig. Közigazgatási egységeit székeknek nevezték. Az öt történelmi széket (Udvarhelyszék, Csíkszék, Háromszék, Marosszék, Aranyosszék) az 1867-es kiegyezés közigazgatási átszervezése megszüntette, és létrehozta a vármegyéket: Csík, Háromszék, Udvarhely és részben Maros-Torda vármegye. Az 1968-as megyésítés újra átalakította a közigazgatási formát, létrejött Hargita, Kovászna és Maros megye. A lakosság etnikai összetétele: magyar, román, roma és egyéb nemzetiség. A magyar lakosság a történelem folyamán mindvégig többségben volt, 74 \% feletti magyarságról beszélhetünk. Az 1920-ik évi hivatalos román statisztika megállapítása szerint (melyben az 1910-es utolsó magyar népszámlálás adataihoz képest igen sok községben megfigyelhető a magyar lakosság számának célzatos visszaszorítása) Székelyföld 17406 négyzetkilométer területén 723528 lakos él, ebből 74,68\% magyar, 21,71\% román, 0,96\% német, 1,32\% zsidó, egyéb lakos 1,33\% (Páldy 2009: 533). Amint azt Egyed Ákos is megállapítja a két világháború között a székelyföldi magyarság helyzete egyre romlott: “a román állam a kisebbségbe került magyaroktól nagy értékủ vagyont vett el, de fejlesztéséhez semmivel sem járult hozzá" (Egyed 2006: 288). A huszadik században az erőszakos asszimilációs politika következtében (különösen Maros megyében) erőteljesen csökkent a magyarság száma, de Székelyföld területén még napjainkban is tömbmagyarság él. Hargita megyében, különösen Udvarhelyen és környékén $90 \%$ feletti a színmagyar lakosság. ${ }^{2}$

A székelyek a történelem folyamán mindvégig megörizték identitásuk sarokkövét, nemzeti öntudatukat. Egyed Ákos értelmezésében az igen erőteljes székely MI-öntudat történelmileg alakult ki, és ennek az azonosságtudatnak a fennmaradása annak köszönhetö, hogy a székely közösségi kohézió és azonosságtudat kölcsönösen, egymást erősítve hatott egymásra (291). Nemzeti öntudatuk kifejeződéseként a székelyek hüen őrzik hagyományaikat, népi kultúrájukat. A Trianon utáni román beolvasztási eltökéltség identitásuknak ezt a sarokkövét akarja kimozdítani a helyéből vagy legalább fellazítani, réseket ütni rajta. Az általam felvett szépirodalmi példák a korszak identitáskálváriáinak széles skáláján mutatják be ezt a hegemonikus államhatalmi nyomulást és következményeit: a székelymagyar nemzeti identitásbeli megalkuvást, a székely közösségből való kivettetést, az egzisztenciális ellehetetlenülést, a lavírozó/rejtőzködő magamentést, úgyszintén a megalkuvásmentes identitásőrzést—az identitásmenedzselés különféle stratégiáit. A székelység válaszreakciói ezek az interetnikus, interkulturális környezetben elfoglalt kisebbségi helyzet kihívásaira, az identitáselhagyó-konformizmustól a jól menedzselt identitásgerinc-megtartásig. Ezekkel együtt a székelység elszegényedése, az elrománosodás és a kivándorlás, a szülöföldelhagyás, a magyar arisztokrácia román jobbágyot favorizáló nemzetrontó önzése, a beolvasztási politikát szolgáló román bankpolitika is fontos témája a Trianon utáni erdélyi magyar irodalomnak.

\footnotetext{
${ }^{2}$ A 2011-es népszámlálási adatok Udvarhelyszéken 96\%-os magyar lakosságot mutatnak. A táblázat címe: Populația stabilă pe sexe, după etnie - categorii de localități, macroregiuni, regiuni de dezvoltare și județe (román nyelven) (xls) ['Stable Population of Gender and Ethnic Group - According to Location, Macro-Regions, Developing Regions, and Counties']. Institutul natțonal de Statistică. [2015. február 15.]
} 
Dani, Erzsébet. "Székelymagyar nemzeti- és kulturálisidentitás-stratégiák a trianoni határokon túl (SzékelyHungarian National and Cultural Identity Strategies beyond the Trianon Borders)." Hungarian Cultural Studies. eJournal of the American Hungarian Educators Association, Volume 9 (2016): http://ahea.pitt.edu DOI:

\section{A két világháború közötti székelymagyar irodalom}

Trianon hatása az erdélyi kultúrára, oktatásra, magyar nyelvre, a kulturális és oktatási intézmények sorsára egyértelmüen negatív, de mégis léteznek olyan változások, melyek következtében pozitív folyamatok indultak el, például az irodalom területén (Dani 2010: 98). Ezekben az években tüntek fel azok az írók, akiket a kisebbségi létforma érlelt íróvá: Tamási Áron, Nyirő József, Kacsó Sándor, Kemény János, Karácsony Benő (Pomogáts 1994: 30-31). Ekkor lépett színre "Tizenegyek" néven az első szervezett írói csoportosulás is, melynek tagjai közé tartozott: Balázs Ferenc, Dobai István, Finta Zoltán, Jakab Géza, Jancsó Béla, Kacsó Sándor, Kemény János, Maksay Albert, Mihály László, Szent-Iványi Sándor és Tamási Áron. Fellépésük meghatározó jelentőségủ volt úgy az erdélyi, mint az összmagyar irodalom számára (Cseke 2015 web: 1). Az általam felvett regények közös vonása az, hogy mindegyik székelymagyar író tollából született, és a székelység sorskérdéseivel foglalkozik.

\section{A müvek és az identitásmenedzselési formák}

Releváns modern elméleti fogódzók segítségével ${ }^{3}$ vizsgálom tehát Ignácz Rózsa (Született Moldovában ['Born in Moldova'], Anyanyelve magyar ['Native language: Hungarian']), Tamási Áron (Ábel ['Abel']), Bözödi György (Romlás ['Decline']) munkáit. Több müben hangsúlyosan megjelenik a szórványmagyarság kérdésköre is, tovább szélesítve az identitásmenedzselési típusok skáláját. A szövegek elemzésével választ keresek arra, hogy milyen identitásválság-menedzselési stratégiákat követel és alakít ki a kisebbségbe/szórványlétbe szorult nemzetiségek sajátos helyzete, illetve hogyan alakul át az interkulturális kommunikáció és milyen formákat ölt. Továbbá arra is: beszélhetünk-e arról, amit én az identitás-kolonizáció fogalmával írtam le, és a vele járó jelenségekről, amilyen a kulturális mimikri?

Az identitásválság-menedzselési stratégiák kialakítása (erre a jelenségre ezt a fogalmat vezettem be) annak függvénye, hogy az egyén milyen identitástípusú. Az itt felsorolt regényekben megkülönböztethető identitástípusok: a kolonizálhatatlan identitás természetitermészetes, illetve annak sztereotip formája; az önpusztító identitáskolonizálhatatlanság; az identitáselhagyó konformizmus példái; a kulturális emlékezet identitásmegtartó formái; a gyökértelen ÉN-azonosság; a kulturális nacionalizmus identitástorzója. ${ }^{4}$ A torzult és kevésbé deformálódott identitásnak még számos válfaja jelenik meg, de ezekre itt nem térhetek ki. Mindenesetre, két típus következetesen előfordul mindegyik regényben, a maga változataival: a kolonizálhatatlan identitás és az identitáselhagyó konformizmus.

Előbbi identitásforma egyik legjellemzőbb és legmarkánsabb képviselője Tamási Áron Ábel-trilógiájának Ábelje, aki a székely nép és nemzeti öntudat szimbóluma lett, a székely közösségen belül és kívül. Útja, hasonlóan Tamásiéhoz, Székelyföldről indul, és ott fejeződik be. Ábel minden átélt kalandban megőrzi nyugodtságát, a bajban előveszi székely eszét,

\footnotetext{
${ }^{3}$ Az elméleti háttér kifejtésére itt nincs lehetőség. Identitásgyarmatosítás Erdélyben ['Identity-Colonization in Transylvania'], c. könyvemben fejezetet szenteltem a kérdéskörnek. Jelen írásban az elméleti fogalmak rövid magyarázatát minden esetben lábjegyzetben fogom megadni.

${ }^{4}$ Jelen tanulmányban csak ezzel a két típussal foglalkozom részletesen. A többi típus és az azokat képviselő regényfigurák részletes elemzése fent említett könyvemben megtalálható.
} 
Dani, Erzsébet. "Székelymagyar nemzeti- és kulturálisidentitás-stratégiák a trianoni határokon túl (SzékelyHungarian National and Cultural Identity Strategies beyond the Trianon Borders)." Hungarian Cultural Studies. eJournal of the American Hungarian Educators Association, Volume 9 (2016): http://ahea.pitt.edu DOI:

rácsodálkozik a világra, de nem engedi neki, hogy bármiben is megváltoztassa. Önazonosságát minden körülmények között megőrzi, a csalódások és kiábrándulások ellenére; a maga belső törvényei szerint ítél, mert igénye van arra, hogy értelmezze magának a világot. Útjának három állomása Tamási életútjának három szakasza: Farkaslaka, Kolozs vár, Amerika. A szerző személyes élményeit is megjelenítő regény talán ettől is ennyire "ábeli." Ábel identitásfejlődésének három szakaszát figyelhetjük meg: a természeti- természetes formát, az identitásgerinc alapú interkulturális kommunikációs formát és a kiforrott kolonizálhatatlan identitást.

Az első- a természeti-természetes székelynek nevezhető—szakaszban (Ábel a rengetegben)Ábel számára az identitás magától értetődő, a Hargitán ${ }^{5}$ nem igazán érzékeli Trianon hatásait. A zárt székely faluban a mindennapi gondok, a megélhetés kérdései álltak előtérben. Az ottani élet nem kívánt Ábeltől többet, mint a korosztálybeli székely fiúktól. Életének dimenziói, szavait kissé átfogalmazva, "a Hargitán való uralkodásával” (Tamási 2011: 46) tágulnak ki, paradox módon, hiszen ekkor magára marad a "rengetegben." Ember nincs körülötte, és ekkor, kutyája társaságában, kezdi felfogni az életet. Az emberekhez való viszonya emberhiányos környezetben kezd kinyílni. A természeti ember abban is megnyilvánul benne, hogy a hargitai rengeteg nagy természeti kihívásai kisebb gondot jelentenek számára, mint a hozzá (az erdőpásztorhoz) kilátogató, vele üzletet kötő ember emberek. A természettel mindenkor harmóniában tud élni, a diszharmónia az emberekkel jelenik meg ebben a világban. Találkozásai a pénz, a kisebb-nagyobb csalások, a hit és a nemzeti kérdések világával, fokozatosan alakítani kezdik világról alkotott nézeteit.

A nemzetiségi kérdéssel is ábeli módon találkozik. A zárt székely közösségben nevelkedett fiú nem ismeri azt. Mindenkihez emberként közelít, mindenkiben az embert nézi. Az útjába kerülö "Másság”-ot sem másságként érzékeli, illetve az érzékelt másságot sem kezeli "Más"-ként. Neki természetes az, ha valaki más nyelven beszél, vagy csak töri a magyart. Nincsenek negatív sztereotípiái a román emberekre vonatkozóan. Következésképp nem is tud mit kezdeni azzal, ha az országosan többségben lévő (román) nemzet ${ }^{6}$ erőszakos módján próbálnak közelíteni hozzá. Nem érti, de érzi, és a maga tréfás módján igyekszik kezelni ezeket a nemzetiségi konfliktus-helyzeteket, amikor először találkozik velük. Amikor az első hargitai látogató román ellenségként mutatkozik be, az etnikai ütközésben még járatlan székely a világot széles keblére ölelő nemes természetességgel reagál: nem fogadja ellenségként a román csendőrt. Ábel zárt térben kommunikál. Elöször önmagával beszél meg mindent: a kifelé adott válasz belső kommunikációs térben születik meg. Az ő esetében ez a létezés és a kommunikáció természetes módja. Nem stratégia, nem önazonossági csaták közbeni, és identitás-vereség utáni visszavonulás terepe. A természeti-természetes székely belső kommunikációs tere is tömör és egyszerü, a belső tanakodást természetesség és esszenciális fogalmazás jellemzik.

Interkulturális kommunikációról az ő esetében itt még csak az egyén szintjén beszélhetünk, hiszen Ábel ön- és világmegismerési útjának első terében csak ez a forma

\footnotetext{
${ }^{5}$ Hargita hegység a Keleti-Kárpátokban.

${ }^{6}$ Országos többséggel - minthogy a románság országosan rendelkezik többséggel (ahogy Erdélyt tekintve is), de a Székelyföldön, ahol Ábel él, a székelyek alkotják a többségi nemzetet.
} 
Dani, Erzsébet. "Székelymagyar nemzeti- és kulturálisidentitás-stratégiák a trianoni határokon túl (SzékelyHungarian National and Cultural Identity Strategies beyond the Trianon Borders)." Hungarian Cultural Studies. eJournal of the American Hungarian Educators Association, Volume 9 (2016): http://ahea.pitt.edu DOI:

valósulhat meg. Egyéni kommunikációs szinten sikeres konfliktus-kerülgetéssel, vagyis eredményesen kommunikál. Véleményét bátran megfogalmazza, az esetlegesen kialakuló konfliktusos helyzet élét humorral veszi el. Nem konfrontálódik feleslegesen, vitába csak akkor bonyolódik, ha becsülete, önérzete megkívánja. Ilyenkor megvédi igazát, de sosem bántó módon. Az egyéni kommunikációs térben ez a stratégia müködik, nem generál megoldhatatlan konfliktusokat. A hargitai elszigeteltség interkulturális csoportkommunikációra viszont nem ad lehetőséget, ezért Ábel nem tudja kipróbálni magát benne. A fentiek alapján mimikriről beszélhetünk, de ez nem a Bhabha ${ }^{7}$ elméletében szereplö, és a kisebbségi székelymagyar túlélési manőverezésben egyébként gyakran alkalmazott stratégia. Nem igazi kulturális mimikri. Ábelnek nincs szüksége ilyesmire. Az ő módszere a furfangos székely kikerülő játékossága. Ahogyan majd fokozatosan kilép a társadalmi színterekre, találkozik az erdélyi nagyobb település, majd az amerikai társadalom etnikai és kulturális sokszínűségével, úgy jut egyre nagyobb szerephez az Ábelben a kulturális mimikri, de akkor is oly módon, hogy nem alkalmazhatók rá a Bhabha-féle kulturális mimikri-fokozatok.

A trilógia második kötetében (Ábel az országban) Ábel azonosságtudata más jelenségeket produkál. Úgy mondhatjuk, hogy az identitásgerinc és az erre alapuló interkulturális kommunikáció szakaszába lép. Miután önként elhagyja a rengeteget, a városba igyekszik. A madéfalvi állomáson ismeri fel, hogy élete komoly stációjához érkezett. Madéfalva mint a világba való kilépés kiindulópontja nem lehet véletlen, hiszen Ábel a Hargitát és a zárt székely kisközösséget maga mögött hagyva, Madéfalva "kapuján" át mintegy belép a székely történelembe, melynek a kollektív emlékezetben örzött egyik nagy traumája éppen a madéfalvi tragédia. ${ }^{8}$ A Madéfalvára vezető úton a román bakterrel való találkozással tudatosul benne igazán a kisebbségi lét nyomorúsága. A Hargitán egy román csendőr révén ugyan a saját bőrén tapasztalta, ki az úr és ki a szolga az erdélyi interkulturális létben, a csendőr mégis csak egy ember volt. A hegemonikus arrogancia általános érvényüségére a román bakter tanítja meg. Ebben a helyzetben érzi először, hogy diszkriminált kisebbség tagja, először alázzák meg azzal, hogy: "Kuss, minoritar!" (= Kuss, kisebbségi) (260). A román szót nem érti, de érzi, hogy porig alázzák. Az egyéni interkulturális kommunikációban addig jeleskedő Ábelt ez megzavarja. Hirtelen mintha itt már nem lenne elegendő a korábbi kommunikációs habitus: a humor és az agyafúrt válasz. Megriad, nem tudja kezelni a helyzetet, mert mindig azt gondolta, hogy legyen bár magyar vagy román: "szegény ember mind együvé tartozik, s ha hadakozni kell valaki ellen, akkor a szegénynek kell a gazdag ellen, s a jó embernek a rossz ember ellen" (260). Ez egyben Ábel következetessége is, hiszen az első könyv végén, a Hargitáról lejövet az édesanyja sírjánál megfogadja: "hogy a szegények és az elnyomottak zászlaját fogom hordozni” (220), vagyis

\footnotetext{
${ }^{7}$ Homi K. Bhabha bevett kategóriája a mimikri, mely szerint a gyarmatosító és a gyarmatosított közötti kapcsolatban a gyarmatosított úgy tesz, mintha elfogadná a gyarmatosító kultúráját, viselkedését, felvenné szokásait. Ezen viselkedésnek 3 eredménye lehet: valójában így rejtve maradva őrzi és védi saját kultúráját; miközben megjátssza a látszólagos alkalmazkodás szerepét, közben maga is átalakul valamennyire a gyarmatosító hatása alatt; ebben a folyamatban keverék kulturális reflexsor alakulhat ki.

${ }^{8}$ A “madéfalvi veszedelem"-ként fennmaradt kegyetlen székelymészárlás, melyet az osztrák hadsereg rendezett 1764. január 7-én.
} 
Dani, Erzsébet. "Székelymagyar nemzeti- és kulturálisidentitás-stratégiák a trianoni határokon túl (SzékelyHungarian National and Cultural Identity Strategies beyond the Trianon Borders)." Hungarian Cultural Studies. eJournal of the American Hungarian Educators Association, Volume 9 (2016): http://ahea.pitt.edu DOI:

ennek alapján ítélné meg az embereket és a világot - ha a román hegemonikus gőg ezt neki, a kisebbséginek hagyná. A román bakter maga is meglepődik azon, ahogy a székely fiú reagál a bakter által természetesnek és igaznak hitt kijelentésre. Megérzi, hogy a szuverén szellemü székely rászorul a "felvilágosításra": "De jegyezd meg magadnak, hogy mert ebben az országban mi vagyunk az urak: románok!" (260). Így fest tehát az a helyzet ahol már nem elég a játékoshumoros riposzt. Ábel felfogja a bakter magyarázatát, de nem fogadja el. Nem veszi fel a kesztyüt, de nem is hajt fejet: "én nem akartam megsérteni a tekintetes urat. Csupán azt gondoltam, hogy mind a ketten munkával keressük a kenyerünket, s eléfelé törekszünk. Most ellenben látom, hogy a tekintetes úr román, aki uralkodhatik, én pedig szegény székely-magyar vagyok, akinek nem szabad kibeszélni érzelmeimet" (261). Ez már maga a kinyilvánított nemzeti öntudat, és ennek az identitásnak elrejtő menedzselése, mely viszont még nem mutatja a Bhabhaféle mimikri jeleit. Később, apjának írt levelében így kommentálja szembesülését azzal, ami a Trianon utáni Erdélyben a "város" lényege a kisebbségi székelymagyar számára: “a bakter kinyilvánította nekem azt a kormányzati tételt, mely szerint a románok az ajtó megetti helyet reánk hagyományozták...” (310).

Ábel körül kitágul az interkulturális kommunikációs tér. A társadalomtól elzárt, természeti kommunikációs terepről a nagyközösségi interkulturális térbe bekerülve, sorozatban kerül csoport szintü/csoport értékü kommunikációs helyzetbe. Hiszen az utazó fogorvos zsidó ember; az erdélyi nagyvárosi magyar ${ }^{9}$ nem azonos a hargitai székellyel; az erdélyi szászsággal való találkozásáról nem is beszélve; a hargitai hatalmaskodó egy szál csendőrt pedig felváltja a "sziguranta" ['security service'], vagyis a rendőri szervezet mint a kulturális nyomás mögött álló állami gépezet. Ábel a város interkulturális sokféleségében is óvja székely önmagát. És ennek ára van: úgy tünik, fokozatosan rákényszerül a kulturális mimikrire. A továbbiakban azonban ez mégsem következik be - a városban. Ennek az identitásmenedzselésnek fö sajátossága, hogy a kommunikációs partnerben mindig az egyént látja, mintegy elvonatkoztatva őt a csoporttól. Ábel egyeddé redukálja a csoportot, hogy csoport szinten kommunikálni tudjon. ${ }^{10} \mathrm{Az}$ egyedet a csoportról leválasztva, egyéni kommunikációként kezeli az interkulturális csoportkommunikációt. Ennek világos példája, amikor az ortodox zsidó közösség rituáléjára kíváncsi, és barátságot köt az egyik zsidó emberrel, aki révén eljut a zsidó fürdőbe (vele, egyed az egyeddel, jól kommunikál). Az interkulturális kíváncsiság viszi rá arra, hogy itt a csoport tagjának beöltözve jusson közel a zsidó közösség rituális szertartásához. Tehát Ábel találkozása a zsidósággal is ábeli, a kulturális kíváncsiság motorja nála a kulturális nyitottság (mely a trilógiában mindvégig jellemző rá). Ez a világ nem az ő világa, de meg akarja érteni azt: belehelyezkedni és belülről látni. Meg is mártózik a fürdőben, csakhogy ettől Szakállas Ábelnek lejön az álszakálla, és az interkulturális megértési jó szándék vége mulatságos, mondjuk így: interkulturális kalamajkává válik. Ebben mutatkozik meg a csoporttal való kommunikációs képtelensége: nem vállalja a helyzetet, elmenekül.

\footnotetext{
${ }^{9}$ Kimondatlan marad, de vélhetően Kolozsvárról, mint Erdély fővárosáról van szó.

${ }^{10}$ Karl Erik Rosengren szerint az emberi kommunikáció a következő szinteken valósul meg: az egyén (az individuum) szintjén, csoportszinten, régiós, társadalmi, nemzeti és állam szinten.
} 
Dani, Erzsébet. "Székelymagyar nemzeti- és kulturálisidentitás-stratégiák a trianoni határokon túl (SzékelyHungarian National and Cultural Identity Strategies beyond the Trianon Borders)." Hungarian Cultural Studies. eJournal of the American Hungarian Educators Association, Volume 9 (2016): http://ahea.pitt.edu DOI:

A szórványból érkező, munkanélküli magyar tanító sorsán keresztül pedig a kis sorsokat kisiklató nagy politikai játszmák közelébe kerül Ấbel. A tanító ugyanis, a kisebbségi magyarságot képviselő magyar pártok biztatására megtagadja, hogy felesküdjön a román államra, ezzel is az asszimilációs nyomásnak ellenállandó. Emiatt azonban állását veszíti, egzisztenciálisan veszélybe kerül. Már csak a hazafiság szimbólumaiba kapaszkodik (a szórványban élő magyarságnak már csak a szimbólumok maradtak). Ábel azt is elfogadja, hogy a hazafiság a himnuszon alapul (Ábel számára a hazafiság maga az anyaföldben és a nyelvben gyökerezö létezés), de a nagypolitikai játszma neki túl magas. Úgy is mondhatjuk, hogy Ábel csak az assmani ÉN-identitással ['I identity'] ${ }^{11}$ rendelkezik, a szélesebb társadalmi csoportkontextusban (politika) a MI-identitás ['we identity'] nem értelmezhetö a székely fiú számára. A kisebbségi (nép)csoport elnémításáról szóló felfogás az, ami paradox módon, elnémítja, illetve tönkreteszi az egyént: a magyar pártok stratégiát fogalmaznak meg a csoportelnémítás ellen, ám a csoportelnémítás kivédésére szánt stratégia öngólnak bizonyul az asszimilációs nyomás ellenében, maga vezet az elnémuláshoz. ${ }^{12} \mathrm{~A}$ tanítóval való beszélgetésből a szórványmagyarság ellehetetlenüléséről, és a nagyvárosi magyar kisebbségi pártok öngólos stratégiájáról hallva, a hazafiság kérdéséről filozofálva, fokozatosan fogalmazódik meg Ábelben az, ami a regény fökérdése lesz: mi célra vagyunk a világon? A nagyvárosi és a szórványmagyarsággal való interkulturális találkozásnak ez lesz a világismereti hozadéka.

A bakterrel való találkozása óta Ábel tudja, hogy el kell rejtenie székelymagyar mivoltát, ha meg akarja védeni a hegemonikus nyomástól. Csakhogy a városban ezzel a nyomással nem találkozik. Ezért aztán, miközben eddigi önismereti-világismereti útja felkészítette a mimikrire, a várossal való találkozás mégsem kényszeríti erre a stratégiára. A Trianon utáni erdélyi nagyvárosban még (egyelőre) nem léteznek az állam által gerjesztett, feloldhatatlan ellentétek a lakosság körében (a többnemzetiségü Kolozsváron semmiképp), legalábbis azokban a körökben, amelyekben Ábel mozog. Igaz, mást is megtapasztalhatott volna. Ignácz Rózsa Anyanyelve magyar c. müvének Kovács Ilonája a középiskolában találkozik a magyar oktatást ellehetetlenítő folyamattal. Értelemszerü viszont, hogy az iskolázatlan Ábel nem találkozhat ezekkel a jelenségekkel. Az ö konfliktusai nem nemzetiségi természetűek, magyar azonosságtudatát nem fenyegeti veszély, nincs szüksége identitásválság-menedzselési stratégiákra. Miközben folyamatosan tanul a környezetétől, tágul a világ körülötte, fejlődik az öt ért hatásoktól, megmarad annak a székely fiúnak, aki a Hargitáról indult világot látni. Humorérzéke is változatlan, gondolkodása logikus, sajátosan furfangos, szavai és mondatai tömören kifejezőek. Ábel visszamegy a falujába, hogy feltöltődjön, felkészüljön egy még nagyobb útra, mely Amerikába, a sokkultúrájú tengerentúli országba vezet. Mint látni fogjuk, itt kristályosodik ki benne az, amit kolonizálhatatlan identitásnak nevezhetünk.

\footnotetext{
${ }^{11}$ Jan Assmann így fogalmaz: "az identitás a tudat ügye ['Identity is a matter of consciousnes']”. Az identitásnak szerinte két dimenziója van: az ÉN- és a MI-azonosság, melyben az ÉN növekedése kintről befelé tart, és az egyén saját önelképzelésével és a csoport interakciós és kommunikációs folyamataiban való részvételével épül fel. A MIazonosság, vagyis a kollektív identitás nem létezik a MI-t alkotó egyéneken kívül.

${ }^{12}$ Ez a jelenség megjelenik a Bözödi-regényben, a Romlásban, és Nyirö Néma küzdelem c. regényében is.
} 
Dani, Erzsébet. "Székelymagyar nemzeti- és kulturálisidentitás-stratégiák a trianoni határokon túl (SzékelyHungarian National and Cultural Identity Strategies beyond the Trianon Borders)." Hungarian Cultural Studies. eJournal of the American Hungarian Educators Association, Volume 9 (2016): http://ahea.pitt.edu DOI:

Szülőfalujában, Csíkcsicsóban kemény tanulással készül a tengerentúlra. A helyi református pap karolja fel, szótárakat ad a kezébe, hitét is erősíti, befelé vezeti, Tamási kifejezésével élve: a "szerkesztett vallás"-ba. Ábel úgy indul Amerikába, hogy a második kötet első lapjain kirajzolódik előttünk az út, melyet követni fog: ha a törvényt, vagy apját kell választania, utóbbi mellett dönt; ha pedig a törvényt is választania kell, akkor, mondja az apjának, "Ne búsuljon, mert maga lesz örökké az első paragrafus!" (231). A lelkész kis zacskóban hazai földet nyújt át neki, "kicsi hazai föld, hogy sohase feledkezzél meg az anyaföldről," mely gesztustól és szavaktól Ábel "egyszerre olyan erős lett," hogy úgy érezte, senkitől és semmitől nem fél már (445). Az apa mint "első paragrafus," és az anyaföld együtt maga a kulturális örökség, a kollektív emlékezeti MI-identitás. Erre az útravalóra szüksége is lesz a "zegzugos világ”-ban (269), mert ahogyan távolodik szülőföldjétől, úgy kerül egyre közelebbi ismeretségbe az "ország" különböző nemzetiségeivel. Ezzel még inkább kiteljesedik az interkulturális kommunikációs tér: németekkel, szászokkal, zsidókkal, emigrálni készülő magyarokkal utazik. Az interkulturális kommunikáció akadályai egyre szélesebb skálán jelentkeznek, a nyelvi furcsaságoktól az interkulturális feszültségekig terjedően. A magyar intrakulturális térben jól megérteti magát, sikeresen kommunikál az idegen nyelvü, kulturális mássággal az Európán áthaladó vonaton. Ha interkulturális konfliktus adódik, humorral "üti el". Ábelben a székelymagyar ekkor már tudatos. Ez lépten-nyomon meg is nyilvánul, szavakban és tettekben egyaránt. Interkulturálisan akkor van igazi elakadás, amikor nemzeti öntudatában sértik meg. És amikor ez a vonatfülke zárt kommunikációs terében be is következik a más-más kulturális örökséget és kommunikációs kollektív reflexeket hozó egyedek között, hamar kialakulnak azon kultúrák konfliktusos vagy kevésbé konfliktusos kultúraközi kommunikációját leképező kis szövetségek, melyek most már egymással alkotott csoportos kommunikációban próbálják kezelni vagy tovább feszíteni az interkulturális feszültségeket. A szász csoport nem akarja érteni a magyar csoport humorát, hiszen ellenséget látnak bennük, és az elmérgesedett vita heves pillanatában Ábelt "csavargó székely”-nek nevezik: "Azért, mert te mindig hazudsz! kiáltotta Edmond. - Hazudod, hogy mi egyformák vagyunk, de az nem úgy van, mert én mindegyiknél erősebb vagyok! Hazudod, hogy békesség legyen, de az sem úgy van, mert az erősebbnek kell legfelül lenni, s nem a csavargató eszünek!” (468). Ábelnél ebben a helyzetben csődöt mond az addig jól müködő interperszonális kommunikációs képesség. A komolyra forduló nézeteltérésben ("először éreztem életemben, hogy valami elütő tréfa nem tud kijönni a szívemből, de olyan csúnya szó sem, amit megérdemelt volna”) (469), székely módra, szó nélkül kiveszi a bicskát a zsebéből, kinyitja, és leteszi maga mellé, vagyis a kommunikációt a kudarcos verbális szintről metakommunikációs szintre helyezi át, és ezzel az interkulturális feszültség, mintha nehéz fizikai konfliktusba kezdene átfordulni. Tapintható a jelenetben, hogy a volt Monarchia nemzetiségei csapnak össze egymással; német, szász, magyar nemzeti öntudat néz farkasszemet, mindegyik a maga kulturális sztereotípiáit lovagolva, méghozzá a maga módján: bántó kulturális gőggel, vagy megbántott kultúraféltéssel. Mindez egy vasúti fülkében, ahonnan nem lehet felállni és kivonulni: zárt fizikai térben szigorúan lezáró kommunikációs tér. ${ }^{13}$ Meglehet, ebben a reakcióban a magyar virtus is benne van, de az a lényeg, hogy Ábel

\footnotetext{
${ }^{13}$ Nyirő József Az én népem c. regényében teljes népcsoportok kommunikációja zárt terü.
} 
Dani, Erzsébet. "Székelymagyar nemzeti- és kulturálisidentitás-stratégiák a trianoni határokon túl (SzékelyHungarian National and Cultural Identity Strategies beyond the Trianon Borders)." Hungarian Cultural Studies. eJournal of the American Hungarian Educators Association, Volume 9 (2016): http://ahea.pitt.edu DOI:

magyarságtudata nem bújik a mimikri álarca mögé. Itt már nem kényszerül rá, mint a román bakternél, ahol az elnyomott kisebbség tagjaként találja szemben magát a hegemonikus ideológia megnyilvánulásával, a többségi nyomás más jellegü és más értelemben zárt terében, a kisebbségre rázárt térben, egy állam határain belül. Ezen a vonaton egy felbomlott birodalom évszázadokon át hurcolt kulturális sztereotípiái csapnak össze. Itt azonban senki mögött nem áll államhatalmi gépezet. Itt már, ha tetszik, mindenki kisebbség; mi több, tulajdonképp a kisebbségi sors felé tart, amikor Amerikába igyekszik — még ha meröben másként definiálódik is "a kisebbség” a többkultúrájú amerikai "olvasztótégelyben" (ahogyan akkor még Amerika meghatározta magát), mint az asszimilációs politikájú Romániában.

Amikor Ábel kinyitja a bicskát, beáll a kommunikációs csend, melyben ő magában ismét elmélkedőre fogja a dolgot, és a támpont most is a Hargita: “Az emberi természetről vizsgáztattam az eszemet a csendben, de minél jobban és sóvárgóbban kutattam, hogy valahol egyenes utat találjak, annál inkább kellett látnom, hogy nagyobb rengeteg ez, mint a hargitai!" (469). "Csak egy volt, ami bizonyos volt: az, hogy az emberek között is vannak patkányok és vannak pacsirták, s ezt az egyet is a kutyámtól tanultam. ... kutya hiányában most már nekem magamnak kell megfogni a patkányt, és felröpíteni a pacsirtát" (469). Az Ábel vonatfülkéjében kisszövetségre lépő nagy-kulturális ellentétek, végeredményben tehát, kisebbségi csoportokat fordítanak szembe egymással. A másságot is áthidaló kisszövetségek pedig a közös kulturális emlékezet alapján képződnek. Az Amerikába vezető hajóúton Ábel ebből viszont azt is megtapasztalja, hogy a meröben idegen kultúrákban is megmutatkozhat a közös sors; legalapvetőbb szinten felszínre hozható az, ami az embert köti össze az emberrel. A kommunikációs hajlandóságot nem mutató lengyelországi orosz kereskedőnek (azaz kisebbségben élő embernek), a mindkettőjüknek idegen nyelven (németül) folytatott rövid, tőmondatos kommunikációs kísérlet után, ezt mondja a székelymagyar fiatalember: "milyen kétfélék s mégis egyformák vagyunk" (485). A "kétféleség egyformasága" felismerésben voltaképp az egyformaság kétfélesége az új elem az Ábel című fejlődéstrilógiában, vagyis a fiú önismereti és világismereti útján. Azért fogalmazhatunk így, mert Ábel ugyan megvilágosodik a romániai etnikai diszkriminációt illetően, melyet már a Hargitán megérez a román rendőrben, mígnem a román bakter Madéfalván már kíméletlenül szembesíti vele; úgyszintén tisztában van a társadalmi különbségekkel; mégis, következetesen, demokrata szellemben viszonyul az emberi egyedhez: neki minden ember egyforma, "csak jó embert és rossz embert" ismer (654). Most, amikor felismeri az egyformaságban a kétféleséget, megtanult valamit, tovább lépett. Témánk szempontjából azonban ebben a mondatában is az a legfontosabb, ami Ábel számára is a lényeg benne: hogy a kétféleségben is "egyformák vagyunk". Vagyis a szerző itt is előtérben tartja Ábelnek ezt a demokratikus alapnézetét, mely végig vonul a trilógián. Elvégre Ábel ezt az álláspontját adja elő a román bakternek, a vonaton a németeknek és a lengyelországi orosznak, majd később Amerikában a bankigazgatónak, amikor utóbbi megleckézteti, mert "négerrel együtt látta". Ábel Hargitán formálódott identitásgerincének egyik fö alkotóeleme ez (a "Hargitá"-t szélesebben, kulturális örökségként is értve). És a sokféleségben látott egyféleség nem más, mint identitása kolonizálhatatlanságának garanciája. Az egyformaságnak is vannak viszont változatai, melyek riasztóan hatnak Ábelre. Mert míg Ábel szemében minden ember egyforma, univerzálisdemokratikus értelemben, attól egyén marad és szuverén, megkülönböztethető kulturális identitással, és azon túl azzal a többlettel mely őt egyéníti, egyéniséggé teszi. Amerika partjait elérve viszont szembetalálkozik az olvasztótégely-ideált közvetítő egyformasággal, melyet Tamási öltözködési jelképességgel sugall: "Mindegyik férfiúnak fehér színü és kemény 
Dani, Erzsébet. "Székelymagyar nemzeti- és kulturálisidentitás-stratégiák a trianoni határokon túl (SzékelyHungarian National and Cultural Identity Strategies beyond the Trianon Borders)." Hungarian Cultural Studies. eJournal of the American Hungarian Educators Association, Volume 9 (2016): http://ahea.pitt.edu DOI:

szalmakalap volt a fején, mintha nem is vegyes emberek, hanem valami egyöntetü társaság jött volna ily korán a fogadásunkra" (488). Az olvasztótégelyre utaló egyöntetűség is kolonizálja az identitást, csak nem asszimilációs erőszak révén. A kulturális identitás feladásával jár. Hogy is ne hökkentené meg azt, aki keményen ön-azonos, akinek identitásgerince van? Ábel rosszalló elcsodálkozásában a székelymagyar identitás féltése retten meg az első amerikai benyomástól.

Az Újvilágban Ábel aztán egyik munkahelyről a másikra hányódik, mert sorozatosan konfliktusai támadnak. A nagy különbség az Újvilágban az, hogy ezek a nézeteltérések nem nemzetiségi jellegủek, mint a Hargitán, az országban, és az Amerikába vezető úton voltak. És nem azért, mert etnikai olvasztótégelybe került. Ha nem is nemzetiségi, de etnikai jellegü konfliktusai ugyanis támadhattak volna, hiszen ilyenek osztják meg még a minden-emberegyenlő ${ }^{14}$-gondolatra épülő Újvilágot is. A bőrszín kérdésével Ábel még sosem szembesült, ugyanis az Erdélyben tapasztalt diszkrimináció nem bőrszín szerinti volt, hanem nemzeti(ségi) alapokon állt. Éppen ez a mentalitás keveri nehéz helyzetbe, amikor, például, neki "a néger orvos is jó" (646). Amikor pedig egy filippi ember vágja a fejéhez, hogy "a fehér nem ember" (544), elhatározza, hogy ha testileg nem is képes rá, lélekben ő lesz az erősebb mindenkinél, aki ilyen kijelentéseket tesz. Megint a minden-ember-egyforma elv érvényesül, vagyis Ábel nem fajgyülölő, és nem is lehet belőle fajgyülölőt csinálni. Ezzel együtt és ettől függetlenül, attól a pillanattól kezdve, amikor hiábavalóan igyekszik az amerikai vámossal hargitai szellemben kommunikálni, úgy érzi, ebben az országban másképpen jönnek a gondolatok, főként pedig a "szó meghalt" (490-491). Többet jelent ez annál, hogy angol nyelvtudása is kezdetleges: a székely észjárásos érvelés az, ami Amerikában nem müködik.

Az etnikailag sokszínủ Amerika a székely identitású egyént is befogadja, itt nem szorítják be az ajtó mögé pusztán székelymagyar identitása miatt. Ennek a társadalomnak a csoportjai között azonban nincs ott az övé. Gáspár bácsi, a csíkcsicsói Kelemen pap rokona, akihez érkezik, már amerikanizálódott magyar. Amikor a székelységébe egyre tudatosabban kapaszkodó Ábel, a közös székely származásra hivatkozva Gáspár bácsi segítségét kéri, nem tud mit kezdeni az amerikanizálódott székelymagyar bevándorló reakciójával. "Az igaz, hogy se nem apám maga, se nem rokonom, de mégis van egy nagy dolog, amiben életünk végéig egyek vagyunk... Mi az? - kérdezte [Gáspár bácsi]. - Az, hogy székelyek vagyunk. [Gáspár bácsi] Csúnyán nevetett, és rögtön azt mondta: Köpöm rá!” (552). Gáspár bácsi az amerikai olvasztótégelyben a Yinger- és Hess-féle akkulturációs szinten áll, melynek egyenes következménye az asszimiláció-ez esetben önkéntesen és nem erőszakos külső nyomásra. Ábel ÉN-identitásának ily módon Amerikában nincs külső MI-identitás-támasza. Igaz, magyar honfitársakkal is találkozik, így a velük használt magyar nyelv némi biztonságérzetet nyújt neki, de ez nem jelent székelymagyar csoporttámaszt. Végeredményben csak a magában hordozott kulturálisidentitás-reflexekből táplálkozhat. Egyéb vonatkozásban is úgy érzi, szétszedi a sokszínü világ, vagyis erre a belső forrásra fokozottan vigyáznia kell. És nem is marad teljesen egyedül. Toldi Miklós amerikai magyarban megtalálja azt a húrt, mely rezonál Ábel székelymagyarságára. Benne lel társra a

\footnotetext{
14 'All men are created equal' (Vecseklőy József hivatalos fordításában: “minden ember egyenlőnek teremtetett”)— "Az amerikai Egyesült Államok népének Függetlenségi Nyilatkozata" (sic!) híres indító érve, mindjárt a második bekezdés első mondatában.
} 
Dani, Erzsébet. "Székelymagyar nemzeti- és kulturálisidentitás-stratégiák a trianoni határokon túl (SzékelyHungarian National and Cultural Identity Strategies beyond the Trianon Borders)." Hungarian Cultural Studies. eJournal of the American Hungarian Educators Association, Volume 9 (2016): http://ahea.pitt.edu DOI:

kétszemélyes MI-csoporthoz, melyet ezután ők ketten alkotnak. Ami a puszta rezonanciánál sokkal több: Ábel elhatározása (miszerint visszatér szülőföldjére) Toldit is arra készteti, hogy 16 év amerikai tartózkodás után megtérjen Nagyszalontára, szülővárosába, mert, mondja Toldi, nyilván Ábel elhatározását minősítve: "ha egy székely csinál valamit, az nem lehet rossz” (665). Magában Ábelben pedig megvan ennek az elhatározásnak a régen érő logikája: “Amikor én otthon az országban jártam, s amikor külországokon keresztül ide eljöttem, örökké csak azt láttam, hogy csakugyan nem a legjobb székelynek s egyáltalában magyarnak lenni. Mert kicsi nép az: sokkal kisebb, mint ahogy az esze és az embersége után megérdemelné" (553). A kulturális megengedés légkörében tehát Ábelnek, vagyis "a túl kicsi nép" fiának, túl nagy a kultúrák sokasága. Úgy érzi, saját kultúrájának nem jut elég levegő. Az amerikai magyarság lassan enyésző nemzeti tudata Ábelt látszólag nem zavarja, de ő maga a tendenciával nem tud azonosulni. Az asszimiláció révén történő nemzeti és kulturális identitás feladásában rémképet lát. Például a felvidéki magyar származású kaszinótulajdonosban (akinek a pénz az istene), aki magyarságtudat szempontjából már Gáspár bácsinál is menthetetlenebb: “az ő magyarságára ne sokat alapítsak, mert ő a magyart hamarabb kívül teszi a kapun, mint a másféle nemzedéket" (623-624).

A kaszinótulajdonosokkal és a Gáspár bácsikkal ellentétben Ábelt nem a gazdag jövő reménye hajtja, hanem székelymagyarságának jövője foglalkoztatja, ugyanis annak a világnak, amelyet Amerika jelent, rendkívül erős a befolyásoló, átalakító képessége: “nemcsak mi uralkodunk a világon, hanem a világ is uralkodik rajtunk. Vagyis hiába hirdetik a papok, hogy az Isten a maga képére teremtette az embert, mert ebbe belészól a változatos élet is: az egyikből Leupoldot csinál, a másikból délibábos Toldit, s Kelemen Gáspárból pedig amerikait. És vajon belőlem mit?" (512). Ábel végül megteremti a maga kulturális “csoportját," amikor Toldi Miklósban felerősíti a nemzeti-tudatot és a székelyek iránti rokonszenvet. Ök ketten hazamentik kultúrájukat abból, amit kulturális tumultusnak éreznek; illetve abból ahol teljesen elveszíthetnék székely kulturális identitásukat, mert eljutnának a Gordon által “identifikáció”-nak nevezett fázisba (Gyurgyík 2011: 151). Mert elveszni a sok kultúra között, vagy asszimilálódni Amerikában sem lenne más, mint a kulturális identitás feladása; nem lenne különb a kulturális identitás kolonizációjánál, még ha merőben más módon és értelemben is, hiszen ez Amerikában nem politikai diktátum nyomására következne be. És a kolonizálhatatlan identitás titka, ezúttal is a Hargitától idáig hozott, és oda visszavitt filozófia, mely szinte vigasztalással fordul Gáspár bácsi felé, amikor az "köp” a székelymagyarságára: "Egy cseppet sem kell búsulni, mert ha valaki mégis elvenné tölünk a mi székelységünket, akkor is maradna valami, amiben örökké egyek lehetünk. Ez pedig semmi egyéb, mint az a nagy dolog, hogy mind a ketten emberek vagyunk" (554). Nemes szavak, nemes gesztus, de mégsem tántorítják el Ábelt attól, hogy akikkel "egyek vagyunk", közösen óvjuk és mentsük a MI-másságunkat. Mert, a trilógia szállóigévé vált mondata szerint, annak a másságnak is helye van a világban: "Azért vagyunk a világon, hogy valahol otthon legyünk benne" (663)—de igazán otthon csak otthon, saját kulturális közegünkben, (MI-identitásunk kulturális terében) lehetünk benne. És az Ábelek számára ez az otthon nem elveszíthető: “Az a furcsa gondolat keringett folyton a fejemben, hogy nem is igaz ez az egész Amerika, csak egyedül az igaz, hogy szép és kies erdélyi hazámat elvesztettem" (516). 
Dani, Erzsébet. "Székelymagyar nemzeti- és kulturálisidentitás-stratégiák a trianoni határokon túl (SzékelyHungarian National and Cultural Identity Strategies beyond the Trianon Borders)." Hungarian Cultural Studies. eJournal of the American Hungarian Educators Association, Volume 9 (2016): http://ahea.pitt.edu DOI:

\section{A kolonizálhatatlan identitás további példái}

A vizsgált identitásdrámák szereplőinek másfajta kolonizálhatatlan identitástípusa Ignácz Rózsa Anyanyelve magyar címü regényének Borbáth Ferenc nevü figurája, aki tudatos és vállalt magyar nemzeti identitással rendelkezik. A regény szintén székelymagyar szereplöje, Ilona, a Kolozsváron tanuló diáklány, Ferenctől kapja azt a segítséget, mely támogatja őt abban, hogy az öt ért román kulturális hatások ne deformálják ÉN-identitását, és a "hamis tudat" ['false consciousness' $]^{15}$ (Rosengren 2000: 50) ne tudja teljesen a hatása alá vonni. Feri jobban eligazodik a kulturális sokszínűségben, hiszen megfordult már más országban, idegen nyelvterületen. A fiatal férfi ÉN- és MI-identitása Ilonát is megvédi attól, hogy alámerüljön az egyre erőszakosabban hömpölygő román kulturális tengerben. Borbáth magyarországi mủegyetemi hallgatóként úgy dönt, hogy befejezi tanulmányait, és hazamegy Székelyföldre, mert ott kíván érvényesülni. Anyaországi tartózkodása alatt még jobban megerősödött benne szükebb hazája iránti elkötelezettsége. Magyar diplomáját azonban Romániában nem fogadták el, ezért "hajléktalanként" dolgozik Kolozsváron, hogy a továbbtanuláshoz összegyüjthesse a pénzt. Sem a nehéz körülmények, sem a folyamatos megaláztatás, sem a kilátástalanság nem szegik kedvét. Megmarad "keményfejű székelynek," erős nemzeti öntudata, érvényesülésvágya megvédi minden asszimilációs próbálkozástól. Jövőképe tiszta: Kovács Ilona férjeként fogja továbbvinni székelymagyar elképzeléseit. Ez kulturális mimikri: látszólag úgy tesz, mintha elfogadná a gyarmatosító kultúráját, de valójában rejtőzködik, őrzi és védi a sajátját. Identitásválság-menedzselési stratégiája többütemü, egymásra épülő fokozatokon keresztül sikerül kialakítania azt a módszert, mellyel Ilonával együtt sikerül megőrizniük nemzeti identitásukat.

Ide sorolható a Született Moldovában címü Ignácz-regény Teréz nevü székelymagyar cselédlánya, aki a román fővárosban keresi a boldogulást. A háború utáni szegénység, a székely falvak munkanélkülisége kényszeríti a fiatal lányt arra, hogy cselédnek szegődjön. ${ }^{16}$ Azok közé tartozik, akik keményen elhatározzák: miután egy kis pénzt összegyüjtöttek, visszatérnek falujukba. Ö is, mint Ábel, útra kel a jobb megélhetés reményében, és visszatér oda, ahonnan elindult. Teréz nem beszél románul, de igyekszik. Erős, tudatos nemzeti azonossága (ÉN- és MIidentitása is szilárd, kikezdhetetlen) segíti abban, hogy ne merüljön alá a bukaresti élet veszélyeiben. Társai közül sokan elkallódnak, magyarságukat, méltóságukat elvesztik, és elvegyülnek a román főváros nyomorúságos negyedeiben, nyomtalanul asszimilálódnak. Teréz szép példája a magyar megmaradásnak. Tudatosan őrzi magyar kultúráját, rendszeresen eljár a bukaresti református magyar gyülekezet istentiszteleteire (kapaszkodva a magyar nyelvbe és vallásba), és ez a kis közösség segít neki kulturális emlékezetének állandó ébrentartásában. Kulturális rejtőzködéssel féltve örzi nemzeti tudatát, miközben megtanul románul. De nem felejti anyanyelvét sem. Úgy lesz kétnyelvü, hogy közben magyar anyanyelve nem erodálódik.

\footnotetext{
${ }^{15}$ A "hamis tudat ['false consciousness']” a marxi filozófia kategóriája: a társadalom az önámítás állapotában leledzik. A rosengreni felfogásban a "hamis tudat"-tal száll szembe az "ideológiai kritika ['ideological critique']” éspedig úgy, hogy vállalkozik az elfogadott társadalmi ideológiák leleplezésére.

${ }^{16}$ A két világháború között (a folyamat már a 19. században elkezdődött) a Székelyföldről tömegek indultak szolgálni a román fővárosba. Székely cselédlányok és szolgalegények lepték el Bukarestet.
} 
Dani, Erzsébet. "Székelymagyar nemzeti- és kulturálisidentitás-stratégiák a trianoni határokon túl (SzékelyHungarian National and Cultural Identity Strategies beyond the Trianon Borders)." Hungarian Cultural Studies. eJournal of the American Hungarian Educators Association, Volume 9 (2016): http://ahea.pitt.edu DOI:

Interkulturális kommunikatív képessége kiváló, a neki munkát adó román nagyasszonyoknak megadja a tiszteletet, rejtőzködő mimikrivel húzódik meg munkája mögött, és csak akkor kommunikál, ha feltétlenül szükséges. Teréz nincs identitásválságban. A multikulturális környezetben azonban mégis kialakítja a maga stratégiáját: fölteszi a rejtőzködés álarcát. Esélyt sem ad a hamis tudatnak arra, hogy megzavarja ÉN-identitását. Ezzel sikeresen ellenáll a körülötte áldozatokat szedő beolvasztó manipulációnak.

Nem mindenki képes viszont az ellenállásra, illetve nem mindenkinek hagyják ezt a körülmények. Ezekben az esetekben jelenik meg az a véglet, amikor identitás elhagyásról beszélhetünk. Az identitáselhagyó konformizmus példái mindegyik regényben megtalálhatók. Szinte “elrettentő" példaként jelennek meg, különböző formát öltve, de azonos társadalmi jelenséget formázva. Talán a legsikeresebben megrajzolt figura a Született Moldovában címü Ignácz-regény Gergely Bélája, aki Adalbert Gherghelivé válik. Ezek a szereplők úgy menedzselik fel sem ismert identitásválságukat, hogy nem törődve a kulturális emlékezettel, a saját kulturális közegből való kiszakadással, feladják magyar nemzeti identitásukat, új identitást öltenek magukra—negatív előjelű stratégiát folytatnak. Az eredetileg székelymagyar Gergely Béla az identitásfeladó-konformizmus vegytiszta példája. A nagyravágyó férfi politikai és gazdasági okokból, tudatosan tagadja meg magyarságát, cseréli le református hitét ortodoxra, változtatja nevét románra, vesz feleségül román nőt. Elméleti terminológiánkkal élve, a Hessmodell fokozatait: szegregáció, akkomodáció, akkulturáció, asszimiláció, amalgamáció (Gyurgyík 2001: 152-153) járja be, úgy, hogy az öt lépésből kimarad az akkomodáció szakasza. Gergely Béla a szegregáció de facto és de jure formájával egyaránt találkozik: felismeri, hogy kisebbségiként nem tud érvényesülni. Ezért, tudatosan és jól megszervezetten, az akkulturáció szintjére lép; elfogadja és magáévá teszi a többségi csoport normáit, értékeit. Az asszimilációban Gergely Béla Adalbert Gherghelivé lesz, akit már szívesen látnak mindenütt: megszünik a személyét ért korábbi szegregáció. Ezen a szinten már a román csoport is kifogástalan városi urat lát benne, aki „nyelvüket tökéletesen beszéli és a franciás könnyedségü bukaresti asszony egyenesen elbájoló (107).” Ghergheli a vegyes házassággal rálépett az amalgamáció utolsó lépcsőfokára, így az asszimilációs modell megvalósulásának tökéletes példája, azzal a “jellegzetességgel,” hogy mindez szabad akaratából történik. Esetében az identitáselhagyókonformizmus a teljes identitáskolonizációval egyenlő. Adalbert nem tartja fontosnak magyarságát, közönyös a történelmi tényekkel szemben, nem látja értelmét az új hatalommal való szembeszegülésnek. Nem kíván hátra nézni, múltjával, gyökereivel azonosságot vállalni, megtagadja ÉN-identitását, annak "új” Személyes szegmensét (Assmann az ÉN-identitást további Egyéni és Személyes szegmensre bontja) (Assmann 2004: 129-131) már a román csoport MI-azonosságához alakítja. Azt a gondolatot képviseli, miszerint előre kell tekinteni, és ott keresni az érvényesülést, ahol lehet. Ha Moldvában, akkor ott. Annyira hisz ebben, hogy beteg feleségét (Dávid édesanyját) is próbálja meggyőzni: "Mindenütt lehet élni. Ha már Romániában kell lennünk, legyünk a szívében, egészen román életformák között. Mit sirat? Erdélyt? Azt a pusztuló, felemás világot odaát? ... Moldova! Pompás hely! Csupa erdő, csupa ragyogás. Illattár.” (28). Identitás-elhagyását azzal magyarázza, hogy gyermekéért, Dávidért is tette 
Dani, Erzsébet. "Székelymagyar nemzeti- és kulturálisidentitás-stratégiák a trianoni határokon túl (SzékelyHungarian National and Cultural Identity Strategies beyond the Trianon Borders)." Hungarian Cultural Studies. eJournal of the American Hungarian Educators Association, Volume 9 (2016): http://ahea.pitt.edu DOI:

mindezt. Ne legyen a fiú idegen a hazájában, és ne jusson "bangyen”-sorsra. ${ }^{17}$ Eltökélt szándéka, hogy fiából “töretlen jellemü románt csinál.” Tehát, a mi nézetünkből: kolonizálódjon a fia identitása is, mint az övé. Dávid magyar édesanyjának halála után felesége emlékét is kitörli az életéből; fiának esélyt sem hagy arra, hogy anyja emlékét ápolja. Egy román családra bízza gyermekét, ő pedig eltünik a román nép nagy tengerében. Majd, románként visszatérve, lépésrőllépésre haladó átgondoltsággal, tudatosan lesz románabb a románnál.

Ezt a típust példázza Bözödi György Romlás címü regényének tanítója, Sebe Ferenc is, aki akaratgyenge, befolyásolható, emberileg sem felel meg annak a feladatnak, melyet a kor interkulturális kihívásai egy székelymagyar tanítóra rónak (ezzel a típussal találkozunk $A z$ én népemben is, Nyirőnél). Híján van a kifinomult gondolkodásnak, szakmai elhivatottság nélkül a mindennapok feladatainak él. Nemzeti identitása a Csepeli-kategóriák szerinti természetes nemzetiidentitás-tudat küszöbét sem éri el. Annyiban székelymagyar, hogy közéjük születik, de az identitás nem kristályosodik benne politikummá, az interkulturális Másikkal szemben pedig végképp nem. Ö is az egyik értelmiségi a faluban, a tanítóság mellet ellátja a kántori teendőket is. Felesége rábeszélésére — “ez ma az élet feltétele” (Bözödi 2002: 9)—az elsők között tette le a románoknak a hüségesküt, így maradhatott a faluban továbbra is tanító, annak ellenére, hogy nem beszéli az állam nyelvét. A falu "kulturális életében" is csak alapfeladatait látja el, az értelmiségi életben nem képvisel szellemi jelenlétet. Véleményt semmiről nem nyilvánít, de ha válaszadásra provokálják, így reagál: "hagyjatok békét a politikával. Nem foglalkozom egyáltalában effélével, hiszen tudhatjátok, állami tanító vagyok. Lehetetlen. Még csak az kellene" (125). Ez arra utal, hogy a politikai viszonyokkal tökéletesen tisztában van, de állásféltésből (a román állam alkalmazottjaként) nem hajlandó székelymagyarságát vállalni. A román templom avatásán is jelen van, de itt sem szólal meg anyanyelvén. Még a mellette ülővel is gagyogás szintű románsággal beszél. A tragédiák tragédiája, hogy a két világháború közötti székely faluban, amikor még nincsenek vegyes házasságok, még nincs általános román fizikai jelenlét (mindössze három román él csak a községben), már olyan megfélemlítő erővel hat a román jelenlét, hogy két magyar a román nyelvet törve próbál egymással kommunikálni: “nem magyar véletlenül? ... Mert nem regátiasan beszél” (253). Sebe és beszélgetőtársa ugyanis az akcentusból jönnek rá, hogy a másik is magyar. A regény nyelvén fogalmazva: ez maga a "romlás," az éltető gyökér (a magyar anyanyelv) pusztítása, azaz identitásgyökér-romlás. A tanító azért erőlteti a román bakadozást, mert célja a magamutogató konformitás. Épp a tanító nem fogja fel, hogy ez a helyzet mennyire szomorú a székelymagyar jövőt tekintve. Renegátsága a mimikriben nyilvánul meg: már gyarmatosított, anélkül, hogy ez egyáltalán érdekelné; ráadásul, annak ellenére, hogy a beolvasztó hatalmi nyomás még aránylag távolról érvényesül. Bhabha mimikri-kategóriájával leírható következmény ez, amikor is a román alkalmazásban álló magyar tanító, vagyis a gyarmatosított identitású ember, azon igyekszik, hogy mutassa: átveszi a gyarmatosító kultúráját, miközben a színlelés kikezdi benne a sajátját. Sebe Ferenc MI-identitása nem müködik, a tudatosság küszöbe alatti ÉN-identitása nem elég erös ahhoz, hogy csoportban tudjon gondolkodni, így tökéletes préda az identitáskolonizáció számára.

\footnotetext{
${ }^{17}$ A “bangyen” olyan román, aki valamikor magyar volt.
} 
Dani, Erzsébet. "Székelymagyar nemzeti- és kulturálisidentitás-stratégiák a trianoni határokon túl (SzékelyHungarian National and Cultural Identity Strategies beyond the Trianon Borders)." Hungarian Cultural Studies. eJournal of the American Hungarian Educators Association, Volume 9 (2016): http://ahea.pitt.edu DOI:

A közösség székelymagyar identitásának ápolása és megőrzése vonatkozásában elég nehéz tehát a helyzet, amikor a tanító kínálja magát a beolvasztó gépezet, a kulturális gyarmatosítás ideális céltáblájául. Mindez katasztrófába torkollik, amikor a falu papjának rosszindulatú feljelentése kibillenti Sebét állásából, és a faluba kultúrzónai román tanító kerül, aki egy szót sem beszél magyarul. Saját terminológiánkra lefordítva: az egyéni szintü, bár a közösségre is kisugárzó tragikus identitásgyökér-romlás már nem csak belülről veszélyeztet, hanem kívülről szervezett állami programmá válik.

\section{Befejezésül}

Végül kísérletet kell tennem arra, hogy válaszoljak a tanulmány elején feltett kérdésekre a megidézett irodalom alapján. Az identitásválság-menedzselési stratégiák alakulása nagymértékben függ attól, ahogyan a MI-identitás hat az ÉN-identitás egyéni és személyes szegmensére. Az instabil, állandó átalakulásban lévő nemzeti öntudat változó stratégiákat fejleszt ki, míg az erős és tudatos nemzeti identitás konfrontálódást és/vagy azonosulást hoz magával. A szórványlét stratégiája a legtragikusabb: úgy tűnik, hogy a kulturális emlékezet (pusztán a vallás) nem elég az asszimiláció elkerüléséhez.

Az interkulturális kommunikáció másként müködik a két (többség- kisebbség viszonyban) nemzet és egy népcsoport esetében. Erős nemzeti tudattal rendelkező csoportok interkulturális kommunikációja csak az egyén szintjén elképzelhető; az egyéntől a csoport és a nemzet felé haladva gyengülö tendenciát mutat—hiszen a konfliktus egyre nagyobb közösségi térben érvényesül—, majd teljesen megszünik (a nagy erejü "hamis tudat"-képzés manipulatív hatása is meghatározó ebben). A kommunikációképességhez az szükséges, hogy az egyén ÉNidentitásának személyes szegmense a más csoportokkal való folyamatos érintkezésben fejlődhessen. A kollektív azonosságtudat egyénre gyakorolt hatása lehet változó, elidegenítő, megsemmisítő és megmentő. Erőteljesen korrelál az ÉN-identitással, illetve annak fejlettségi fokával. Az általam alkalmazott módszerrel elemzett identitásdrámák végkimenetele sok esetben a létező vagy a különféle formákban várhatóan bekövetkező identitás-kolonizáció, melynek velejárója az eltérő eredményeket hozó kulturális mimikri.

Bizonyára eljön az idő, amikor a többségi román nemzet a saját traumájaként fogja kezelni az erdélyi magyarságnak okozott traumát. Az amerikai fehérek ezt már megélték az afroamerikaiak és bizonyos mértékig az amerikai őslakosság (az indiánság) vonatkozásában. Románszékelymagyar viszonylatban erre alighanem sokáig várni kell. Az, hogy a közös és közösségi (azaz, interkulturális) trauma-feldolgozás a trauma-fájdalmat kidolgozza mindkét kultúrából, és ezzel "a társadalmi együttműködés új lehetőségei és formái nyíljanak meg” ['they provide powerful avenues for new formes of social incorporation'] (Alexander 2004: 24; translation by the author), székely/szórványmagyar és román viszonylatban még nem realitás. Pedig a két világháború közti erdélyi székelymagyar azonosságirodalom itt elemzett példái önmagukban elegendőek lehetnének arra, hogy megindítsák ezt a folyamatot.

\section{Works Cited}

Alexander, Jeffrey C. 2004."Toward a Theory of Cultural Trauma.” Cultural Trauma and Collective Identity. ed. Alexander, Jeffrey C. [et al]. Berkeley: U of California P, 1-30. 
Dani, Erzsébet. "Székelymagyar nemzeti- és kulturálisidentitás-stratégiák a trianoni határokon túl (SzékelyHungarian National and Cultural Identity Strategies beyond the Trianon Borders)." Hungarian Cultural Studies. eJournal of the American Hungarian Educators Association, Volume 9 (2016): http://ahea.pitt.edu DOI:

Assmann, Jan. 2004. A kulturális emlékezet: Írás, emlékezés és politikai identitás a korai magaskultúrákban ['Cultural Memory and Early Civilization: Writing, Remembrance, and Political Imagination']. Trans. Hidas Zoltán. Budapest: Atlantisz.

Balogh László. 2001. Románia története ['History of Romania']. [Budapest]: Aula. Print. Bhabha, Homi K. 1998. The Location of Culture. Routledge: New York.

Bodonyi Ilona. 2002. Idők szoritásában: A magyar kisebbség helyzete a szomszédos országokban 1920 és 1933 között ['In the Grip of Times: Hungarian Minority in the Neighbouring Countries between 1920 and 1933']. [Budapest]: Kairosz Kiadó.

Bözödi György. 2004. Romlás ['Decline']. Csíkszereda: Pallas-Akadémia Könyvkiadó.

Cseke Péter. "A Tizenegyek és a székely "írófiak." ['The Eleven and the Writer Székely Young']. web. 25 máj. 2015. http://www.eirodalom.ro.

Dani Erzsébet. 2016. Identitásgyarmatositás Erdélyben: Identitásdrámák és interkulturális stratégiák a Trianon utáni székelymagyar irodalomban ['Identity Colonization in Transylvania: Identity Dramas and Intercultural Strategies in Székely-Hungarian Literature after Trianon'] Csíkszereda: Pro-Print.

—. 2010. "Mi más a többségiből a kisebbségi létbe szorult kultúra esetében?” ['What is Different in Minority Culture'] Mi/Más Konferencia 2010: Gondolatok a másságról. ed. Kádár Judit, Szathmáry Judit. Eger: Eszterházy Károly Főiskola.

Egyed Ákos. 2006. A székelyek rövid története a megtelepedéstöl 1918-ig ['A Brief History of the Székelys from Settlement to 1918'].Csíkszereda: Pallas-Akadémia.

Gyurgyík László. 2001. “Az asszimiláció szociológiai elméleteinek és operacionalizálásuknak egy lehetséges változata a társadalomtudományi kutatásokban." Politika és nemzeti identitás Közép-Európában. ['Politics and National Identity in Central-Europe'] ed. Bárdi Nándor, Lagzi Gábor. Budapest: Teleki László Alapítvány, 149-162.

Ignácz Rózsa. 1990. Anyanyelve magyar. ['Native Language: Hungarian']. [Budapest]: Püski. Ignácz Rózsa. 2011. Született Moldovában ['Born in Moldova']. [s.1.]: Fapadoskönyv.hu.

Kacsó Sándor. 1930. Vakvágányon ['Tail-tracked']. [Brassó]: Brassói Lapok Könyvosztálya.

Nagy Lajos. 1944. A kisebbségek alkotmányjogi helyzete Nagyromániában ['The Situation of Minorities Concerning Constitutional Law in Big Romania']. Kolozsvár: Minerva Irodalmi és Nyomdai Müintézet R. T.

Nyirő József. 2012. Az én népem ['My People']. Szeged: Lazi.

Páldy Pál. 2009. "A székely nép mai helyzete.” ['The Székely Nation Today']. Rugonfalvi Kis István. A nemes székely nemzet képe. Pomáz: Kráter, 529-553.

Pomogáts Béla. 1994. A romániai magyar irodalom ['Romanian-Hungarian Literature']. Budapest: Bereményi.

Romsics Ignácz. 2012. Magyar sorsfordulók 1920-1989 ['Setbacks of Hungarian Fortune 19201989']. Budapest: Osiris.

Rosengren, Karl Erik. 2000. Kommunikáció. ford. Domján Krisztina. ['Communication: An Introduction']. London: SAGE Publications.

Rugonfalvi Kiss István. 2009. A nemes székely nemzet képe ['The Noble Székely Nation: A Portrait']. Pomáz: Kráter.

Tamási Áron. 2011. Ábel ['Abel’]. [s.1.]: Tamási Áron Alapítvány. 